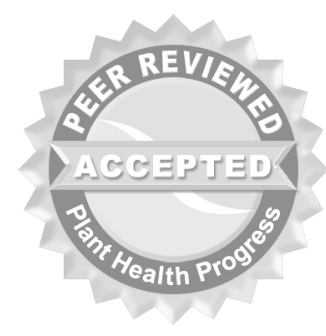

(c) 2006 Plant Management Network.

Accepted for publication 8 September 2006. Published 11 December 2006.

\title{
Seed-borne Fungi Detected in Sugar Beet Seeds Imported into India during Last Three Decades
}

\author{
P. C. Agarwal, Principal Scientist, Baleshwar Singh, Senior \\ Scientist, Usha Dev, Principal Scientist, I ndra Rani, Technical \\ Officer, Dinesh Chand, Technical Officer, and R. K. Khetarpal, \\ Principal Scientist and Head, Division of Plant Quarantine, National \\ Bureau of Plant Genetic Resource, New Delhi 110 012, India \\ Corresponding author: P. C. Agarwal. pcag@nbpgr.ernet.in
}

Agarwal, P. C., Singh, B., Dev, U., Rani, I., Chand, D., and Khetarpal, R. K. 2006. Seedborne fungi detected in sugar beet seeds imported into India during last three decades. Online. Plant Health Progress doi: 10.1094/PHP-2006-1211-01-RS.

\begin{abstract}
Quarantine processing of 1,111 samples of germplasm and inbred lines of sugar beet seed imported into India from 1976 to 2005 resulted in the interception of 10 pathogenic fungi including Uromyces beticola, the beet rust pathogen which is not yet reported from India. Other seed-borne fungi of high economic significance that were detected included Colletotrichum dematium, Fusarium solani, Pleospora betae, and Verticillium albo-atrum as well as other fungal pathogens for which sugar beet is a non-host crop, such as Drechslera halodes, D. rostrata, D. sorokiniana, Cephalosporium sp., and Pestalotia sp. Various fungi detected in sugar beet seed imported from different countries are presented and their economic significance is discussed. Seeds contaminated with $U$. beticola were disinfected by dipping them in concentrated sulphuric acid for 1 min while those infected with $\mathrm{P}$. betae were disinfected by hot water treatment at $50^{\circ} \mathrm{C}$ for 30 $\min$.

\section{I ntroduction}

Sugar beet (Beta vulgaris L.) is second only to sugarcane as the major source of the world's sugar. Its culture is a comparatively recent development, whereas sugarcane culture dates from antiquity. The first beet-sugar factory was built in Silesia (now in Poland) in 1802. In the last century, sugar beet accounted for about two-fifths of the world's sugar production and the major producers were the former Czechoslovakia, France, Germany, Italy, Poland, Romania, Turkey, the UK, the USA, and the former USSR.

The Plant Quarantine Division at the National Bureau of Plant Genetic Resources (NBPGR), New Delhi is the nodal agency for quarantine clearance of imported germplasm intended for research purposes. A large number of economically important fungal pathogens have been intercepted in these imported germplasm including several that are not reported from India (2). Sugar beet seeds in the form of germplasm and inbred lines are being introduced into India for developing cultivars suitable for local agro-climatic conditions. There is always a risk of inadvertently introducing exotic pests associated with such imports. Twenty-two pests (14 fungi, 2 bacteria, 5 viruses, and 1 nematode) are listed as associated with sugar beet seeds (13). Blackleg caused by Pleospora betae (Berl.) Nevodovsky, leaf spot caused by Cercospora beticola Sacc., and beet rust caused by Uromyces beticola (Bellynck) Boerema et al. are the important fungal diseases of beet from a quarantine point of view as they are highly seed-transmitted. U. beticola was introduced into Canada through seeds imported from Europe (8). In this paper, pathogenic fungi intercepted in sugar beet seeds introduced from 1976 to 2005 are reported and their economic significance is discussed. An analysis of data on the level of infection of various fungi in imported sugar beet seed is made by dividing the 30 years of results into three decades. The Decade I is from 1976 (the year of inception of NBPGR) to 1985. The Decade II is from 1986 to 1995 and the
\end{abstract}


Decade III is from 1996 to 2005. This categorization is done in order to analyze the increase or decrease in the risk associated with such imports over the years.

\section{Processing of Germplasm for Quarantine Clearance}

During the last three decades a total of 1,111 samples of germplasm and inbred lines of sugar beet seed from 21 countries comprised of 150 consignments were imported into India for developing cultivars/ hybrids suitable for local agro-climatic conditions. All the imported samples of sugar beet seeds were subjected to the washing test for the detection of U. beticola, beet rust (1), and subsequently to the standard blotter test prescribed by ISTA for the detection of other seed-borne fungi as described below. The number of samples imported from various countries and the fungi detected are presented in Table 1.

Table 1. Seed-borne fungi detected in sugar beet introduced into India during 1976-2005 .

\begin{tabular}{|l|c|c|c|c|c|c|}
\hline \multirow{2}{*}{$\begin{array}{l}\text { Source/ } \\
\text { country }\end{array}$} & \multirow{2}{*}{$\begin{array}{c}\text { Samples } \\
\text { received }\end{array}$} & $\begin{array}{c}\text { C. } \\
\text { dematium }\end{array}$ & $\begin{array}{c}\text { F. } \\
\text { solani }\end{array}$ & $\begin{array}{c}\text { P. } \\
\text { betae }\end{array}$ & $\begin{array}{c}\text { U. } \\
\text { beticola }\end{array}$ & $\begin{array}{c}\text { V. albo- } \\
\text { atrum }\end{array}$ \\
\hline Belgium & 13 & $1(8)^{z}$ & & $5(39)$ & & $2(15)$ \\
\hline Denmark & 127 & & $1(1)$ & $3(2)$ & $4(3)$ & \\
\hline Germany & 198 & & $1(1)$ & $7(4)$ & $6(3)$ & \\
\hline Hungary & 24 & & $3(13)$ & $7(29)$ & & $3(13)$ \\
\hline Iran & 32 & & $2(6)$ & $3(9)$ & & $1(3)$ \\
\hline Italy & 112 & $2(2)$ & $2(2)$ & $15(13)$ & $5(5)$ & \\
\hline Japan & 4 & & & $4(100)$ & & \\
\hline The Netherlands & 51 & & & & $6(12)$ & \\
\hline Poland & 40 & & $5(13)$ & $22(55)$ & & $8(20)$ \\
\hline Romania- & 5 & $4(80)$ & & $4(80)$ & & $5(100)$ \\
\hline Russia & 1 & & & $1(100)$ & & \\
\hline Sweden & 67 & & $2(3)$ & $23(34)$ & $2(3)$ & $6(9)$ \\
\hline The UK & 34 & & & $1(3)$ & $3(9)$ & \\
\hline The USA & 211 & $1(1)$ & $3(1)$ & $4(2)$ & $7(3)$ & \\
\hline $\begin{array}{l}\text { The USSR } \\
\text { (former) }\end{array}$ & 101 & & $1(1)$ & $5(5)$ & $11(11)$ & $1(1)$ \\
\hline
\end{tabular}

x Of the 1,111 samples introduced, 89 samples received from 7 other countries did not reveal any fungi.

y Other fungi intercepted were: Cephalosporium sp. (Italy); Drechslera halodes (Drechsl.) Subram. \& Jain (Italy); Drechslera rostrata (Drechsler) Richardson \& Fraser (Italy); Drechslera sorokiniana (Sacc.) Subram \& Jain (Belgium, Poland); and Pestalotia sp. (Italy).

$z$ Figures outside the parentheses indicate the total number of samples found infected, and within parentheses, the percent of samples found infected.

Washing test. Four hundred seeds from each sample of sugar beet were picked and placed in 16 test tubes each containing $20 \mathrm{ml}$ of distilled water (25 seeds in each tube). The contents of each tube were stirred for 2 min on a vortex stirrer. The liquid was decanted in plastic Petri plates and observed for U. beticola spores under stereo-binocular microscope and initial observations were recorded (1). These seed-washings were centrifuged in tubes at $5000 \mathrm{rpm}$ for $10 \mathrm{~min}$. The supernatant was discarded and three drops of distilled water were added to each pellet. Slides were prepared from the contents of each tube and examined under the compound microscope for the presence of rust spores and final observations of washing test were recorded (1). 
Blotter test. Four hundred seeds from each sample of sugar beet were placed on three layers of moist blotters in 16 plastic Petri plates ( 25 seeds in each plate, 1 in the centre, 9 in the inner circle, and 15 in the outer circle). These plates were then incubated for 7 days at $20 \pm 1^{\circ} \mathrm{C}$ under alternating cycles of 12 - $\mathrm{h}$ light (by Philips 40-W florescent day light tubes) and 12-h darkness. Fungi associated with seeds were identified and recorded on the eighth day under stereo-binocular microscope. When the fungal growth could not be identified under stereo-binocular microscope, slides were prepared and observed under compound microscope (2). The blotter test is being routinely used for the detection of seed-borne fungi in more than 60,000 samples of germplasm and trial material that is introduced every year by NBPGR. Sample size for sugar beet germplasm in the blotter test was usually 400 seeds as we received enough quantity of seed in this crop. In other crops, sample size was dependent on the quantity of seed received (2).

The choice of disinfection method used depended on whether the pathogen was present on the seed surface and/ or along with the seed, as in the case of $U$. beticola, or present inside the seed as well, as in the case of P. betae. Samples of sugar beet seeds contaminated with U. beticola were disinfected by dipping the seeds in concentrated sulphuric acid (98\%) for $1 \mathrm{~min}$ followed by a wash under running tap water as described earlier from this laboratory (12). This technique completely eliminated this rust pathogen from contaminated beet seed (12). Seeds infected with P. betae were disinfected by hot water treatment (HWT) at $50^{\circ} \mathrm{C}$ for $30 \mathrm{~min}$ and subsequently sun dried. Seed samples found contaminated with $\mathrm{U}$. beticola as well as infected with $\mathrm{P}$. betae were disinfected by concentrated sulphuric acid treatment followed by HWT (12). Effectiveness of acid treatment and HWT was tested by washing test (1) and blotter test (12), respectively. Samples found infected with other seed-borne fungi were given fungicidal seed dressing with thiram $2 \mathrm{~g}$ a.i./ $\mathrm{kg}$ seed+carbendazim $500 \mathrm{mg}$ a.i./ $\mathrm{kg}$ seed so as to minimize the chances of spread of fungi along with imported germplasm.

The washing test revealed (Table 1) the presence of urediospores and teliospores of rust, which had characteristics resembling those of the spores of U. beticola (11). U. beticola was first intercepted in India during 1983 in seeds of sugar beet germplasm imported from the USA and Italy. Data presented in Table 1 indicates that this rust was intercepted in 44 samples. These samples were imported from Denmark (four), Germany (six), Italy (five), the Netherlands (six), Sweden (two), the UK (three), the USA (seven), and the former USSR (eleven). Further, a decade-wise analysis of data showed that U. beticola presence remained unchanged in samples from the UK and the USA in Decades I and II, however, in Decade III in samples from the USA its presence was reduced by $80 \%$. Likewise in samples from Germany, the infection levels reduced by more than half in Decade III as compared to the previous decade. Besides sugar beet seeds, U. beticola is reported worldwide on spinach beet [Beta vulgaris cicla (L.) Koch], wild beet (Beta procumbens C. Sm.), and mangold [Beta vulgaris vulgaris (L.) L.] (11). However, it is not yet reported on any host in India. The chances of establishment of a pest upon introduction into the country increases when a greater number of hosts is reported. Severe forms of this rust have been reported from New Zealand, Canada, Denmark, Germany, and Israel (11). U. beticola is a macrocyclic, autoecious rust. Development of this disease is favoured by warm summer weather with frequent light rain or overnight dew because the urediospores can only germinate and infect leaves when surface moisture is present (3). Teliospores of the fungus overwinter on seed and serve as the primary source of inoculum for the crop in the subsequent year (10). Therefore, teliospore contaminated seed clusters must be considered as a potential risk for the introduction of the fungus into new areas since these spores retained viability on seed for 2 years (5). Beet rust was introduced into Canada from Europe through infected seeds (8). In view of the absence of beet rust in India and its seed-borne nature, the interception of $U$. beticola in sugar beet seed is of immense quarantine significance. Rust control by chemicals could give a yield benefit of $7 \%$ (3). Rust infection reduces the root yield and increases the levels of sodium and amino-nitrogen in the extracted juice (4). 
The blotter test revealed a total of 9 pathogenic fungi (Table 1) including those of high quarantine significance and listed as seed-borne in sugar beet (13). Colletotrichum dematium (Pers.) Grove, the anthracnose fungus, was intercepted in 8 samples. These samples were introduced from Belgium (one), Italy (two), Romania (four), and the USA (one). Earlier this fungus was intercepted on introduced germplasm of several crops from Australia, Bangladesh, Belgium, Ethiopia, Hungary, Indonesia, Italy, Nepal, Nigeria, Philippines, Poland, Taiwan, Thailand, the UK, the USA, and Zambia (6).

Fusarium solani (Martius) Sacc. [=Nectria haematococca (Wollenw.) Gerlach] can cause several diseases including blight, wilt, and root or collar rot on various crops. It was intercepted in 20 samples of sugar beet seed. These samples were introduced from Denmark (one), Germany (one), Hungary (three), Iran (two), Italy (two), Poland (five), Sweden (two), the USA (three), and the former USSR (one). Further an analysis of data showed that F. solani infection in samples from Sweden was reduced by $30 \%$ in Decade II as compared to the earlier decade. Earlier, this fungus was intercepted on several crops from various countries (6). F. solani causes substantial economic damage as this fungus has a very wide host range.

P. betae, the blackleg fungus, was detected in 104 samples of sugar beet seeds received from Belgium (five), Denmark (three), Germany (seven), Hungary (seven), Iran (three), Italy (fifteen), J apan (four), Poland (twenty two), Romania (four), Russia (one), Sweden (twenty three), the UK (one), the USA (four), and the former USSR (five). The level of infection remained the same in Decade II and III in samples from Iran, but was reduced almost to half in samples from the USA in Decade II as compared to the previous decade. Likewise, it was reduced drastically in samples from Germany in Decades II (6.6\% seed infection) and III (7.5\% seed infection) in comparison to Decade I (100\% seed infection). Infection level in samples from Sweden also reduced considerably in Decade II (14.2\% seed infection) as compared to the previous decade (61.2\% seed infection). This fungus is one of the primary causes of storage rot of sugar beet. Losses caused by P. betae in storage have been estimated as high as almost 8 million $\mathrm{kg}$ of sugar in some areas in some years, but losses vary (15). Chances of introduction of P. betae into new areas along with seed increases when seed infection levels are as high as 100\% (9). Infection levels of P. betae in seeds was reduced from $27.5 \%$ to $4.5 \%$ after storing the seed at $10^{\circ} \mathrm{C}$ for 13 years at a relative humidity of $59 \%$ (7). This indicates that storage of sugar beet seed reduces chances of introduction of P. betae into new areas.

Verticillium albo-atrum Reinke \& Berthold, the causal agent of Verticillium wilt in several crops was intercepted in 26 samples of sugar beet. These samples were introduced from Belgium (two), Hungary (three), Iran (one), Poland (eight), Romania (five), Sweden (six), and the USSR (one). Earlier, this fungus was intercepted in germplasm samples of several crops imported from many countries (6).

The blotter test also revealed pathogenic fungi for which sugar beet is a nonhost crop, including Cephalosporium sp. in two samples of sugar beet seed from Italy, Drechslera halodes (Drechsler) Subram. \&J ain in one sample from Italy, D. rostrata (Drechsler) Richardson \& Fraser in one sample from Italy, D. sorokiniana (Sacc.) Subram. \&J ain [=Cochliobolus sativus (Ito \& Kurib.) Drechsler ex Dastur] in one sample each from Belgium and Poland, and Pestalotia sp. in one sample from Italy. In the past, D. sorokiniana was intercepted on several crops from various countries (6).

\section{Conclusion}

The seed-health testing of 1,111 samples of sugar beet seed introduced during last three decades resulted in the interception of 10 pathogenic fungi of high economic significance including $U$. beticola, the beet rust pathogen which is hitherto not reported from India, and P. betae, the blackleg fungus, which causes great loss in storage. It is therefore concluded that for quarantine clearance of sugar beet seed, the washing test for the detection of $U$. beticola and the blotter test for other seed-borne fungi are important in order to avoid their introduction into hitherto uninfected areas or areas having limited distribution of these pathogens in the germplasm importing country. Seeds contaminated 
with U. beticola were disinfected by dipping them in concentrated sulphuric acid, those infected with P. betae were disinfected by hot water treatment, while those found contaminated with U. beticola as well as infected with P. betae were disinfected by concentrated sulphuric acid treatment followed by HWT. Samples found infected with other seed-borne fungi were given fungicidal seed dressing with thiram $2 \mathrm{~g}$ a.i./ $\mathrm{kg}$ seed+carbendazim $500 \mathrm{mg}$ a.i./ $\mathrm{kg}$ seed so as to minimize the chances of spreading fungi along with imported germplasm.

\section{Acknowledgments}

We thank all the Directors of NBPGR, New Delhi during 1976-2005 for encouragement and facilities.

Literature Cited

1. Agarwal, P. C., Ram Nath, and Lambat, A. K. 1984. Interception of Uromyces betae in imported sugarbeet seeds. Indian J. Plant Prot. 12:123-124.

2. Agarwal, P. C., Singh, B., Indra Rani, J oshi, K. D., Maurya, A. K., and Khetarpal, R. K. 2004. Pathogenic fungi intercepted in introduced germplasm during 2001. Indian J . Agric. Sci. 74:451-454.

3. Asher, M. 1999. Foliar disease control in 1999. Brit. Sugar Beet Rev. 67:20-21.

4. CAB International. 2004. Crop Protection Compendium. CAB Int., Wallingford. UK.

5. Emdal, P. S., and Foldø, N. E. 1979. Seed borne inoculum of Uromyces betae. Seed Sci. Technol. 7:93-102.

6. Gautam, P. L., and Agarwal, P. C. 1997. Plant Genetic Resources: Some Fundamentals and Beyond. Key note address delivered in the Zonal Meeting of Indian Phytopathological Society during Golden J ubilee Year. New Delhi.

7. Maude, R. B., and Bambridge, J . M. 1985. Effects of seed treatments and storage on the incidence of Phoma betae and the viability of infected red beet seeds. Plant Pathol. 34:435-437.

8. Newton, M., and Peturson, B. 1943. Uromyces betae in Canada. Phytopathology 33:10.

9. Piszczek, J . 1997. Protection of sugar beet seed plants against Phoma betae (Frank). Part I. Effect on seed health and quality. Plant Breed. Seed Sci. 41:61-73.

10. Pozhar, Z. A., and Assual, B. D. 1971. The biology of Uromyces betae, the cause of sugar beet rust. Mikolog. i Fitopatol. 5:166-171.

11. Punithalingham, E. 1968. Uromyces betae. CMI Descriptions of Pathogenic Fungi and Bacteria No. 177. CAB Int., Wallingford, UK,

12. Ram Nath, Agarwal, P. C., Dev, U., and Lambat, A. K. 1986. Quarantine treatment of sugar-beet seed infected with rust (Uromyces betae). FAO Plant Prot. Bull. 34:205-207.

13. Richardson, M. J . 1990. An Annotated List of Seed-borne Diseases. Int. Seed Testing Assoc., Zurich, Switzerland.

14. Smith, E. G., Acharya, S. N., and Huang, H. C. 1995. Economics of growing verticillium wilt-resistant and adapted alfalfa cultivars in western Canada. Agron. J. 87:1206-1210.

15. Whitney, E. D., and Duffus, J. E. 1986. Compendium of Beet Diseases and Insects. American Phytopathological Society, St. Paul, MN. 